\title{
Change in climate and berry composition for grapevine varieties cultivated in the Loire Valley
}

\author{
E. Neethling ${ }^{1, *}$, G. Barbeau ${ }^{1}$, C. Bonnefoy ${ }^{2}$, H. Quénol ${ }^{2}$ \\ ${ }^{1}$ INRA-UVV, 42 rue Georges Morel, 49071 Beaucouzé, France \\ ${ }^{2}$ Laboratoire COSTEL, UMR6554 LETG du CNRS, Université Rennes 2, Haute Bretagne, Rennes, France
}

\begin{abstract}
We analyzed the nature and trends of climate variables and bioclimatic indices for 6 locations situated in the Loire Valley, northwest France, along with the berry composition of the 6 main grapevine varieties cultivated there, from 1960 to 2010. Results show significant increases in mean temperature (by 1.3 to $1.8^{\circ} \mathrm{C}$ ) over the growing season (April to September) throughout the Loire Valley, with maximum temperatures increasing more strongly than minimum temperatures. Temperature variables, such as spring and summer temperatures, the number of days with maximum temperatures $>30^{\circ} \mathrm{C}$ and bioclimatic indices increased significantly. The Huglin Index indicated that the 6 locations in the Loire Valley have shifted from a cool climate to a temperate climate between 1960 and 2010, and increases in growing degree-days were highly correlated with earlier harvest dates. The berry composition of the 6 main white and red grapevine varieties changed significantly, with higher sugar concentrations and lower titratable acidity at harvest. We conclude that these changes in berry composition were significantly influenced by the increases in temperature over the study period.
\end{abstract}

KEY WORDS: Loire Valley $\cdot$ Climate change $\cdot$ Temperature $\cdot$ Bioclimatic indices $\cdot$ Vitis vinifera Sugar concentration $\cdot$ Titratable acidity

\section{INTRODUCTION}

Grapevine development and berry composition are significantly related to their physical environment (Branas 1974, Champagnol 1984, Carbonneau et al. 1992, Van Leeuwen et al. 2004, Carey et al. 2008). This strong relationship is displayed in viticultural regions, where wine grapes are grown in unique 'terroirs'. Terroir is a complex concept, which is defined as the combination of the physical environment, climatic parameters, biological factors and cultural practices influencing the quality and typicity of wine (Vaudour 2003, Morlat 2010, OIV 2010). However, studies have shown that weather conditions during the vintage have a greater influence than the other factors on grapevine development and berry composition (Coombe 1987, Van Leeuwen et al. 2004). Today, with the release of the 4 th report of the Inter- governmental Panel on Climate Change (IPCC 2007), there is a better understanding and increased certainty about global climate change, raising many questions concerning viticulture and wine quality (Bindi et al. 1996, Jones et al. 2005, Webb et al. 2008, Van Leeuwen et al. 2009). In parallel with significantly increased global surface temperatures (IPCC 2007), the mean temperature in France increased by $0.9^{\circ} \mathrm{C}$ from 1901 to 2000 (Moisselin et al. 2002). Along with the increases in atmospheric concentrations of carbon dioxide that underlie climate change, a number of other factors are changing, including rates of evapotranspiration, rainfall variability, summer droughts and extreme high-temperature events (such as the summer heat wave that occurred in 2003 in Europe) (IPCC 2007, Brisson \& Levrault 2010). The grapevine is responding to these climate changes through advances in the key phenological stages, 


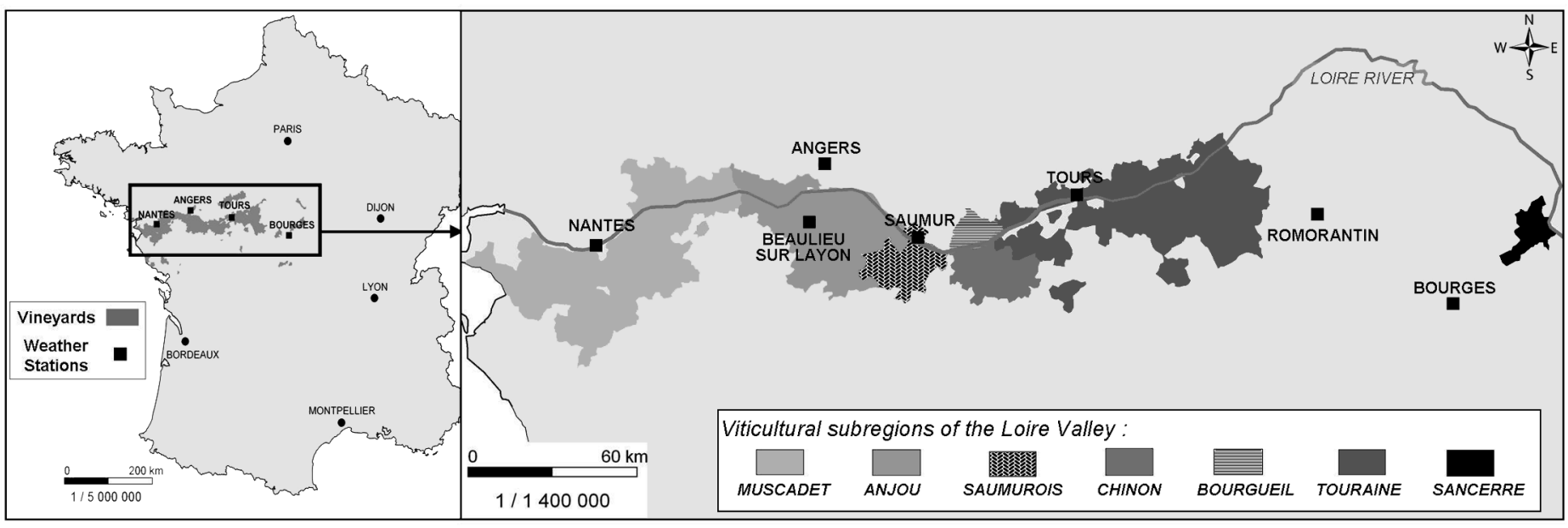

Fig. 1. Loire Valley wine region, situated at $47^{\circ} \mathrm{N}$ in northwest France, between the viticultural sub regions of Muscadet and Sancerre. Map source: Geoconcept 5.6

such as bud burst, flowering, véraison (also known as 'turning' - the stage of berry colouration) and harvest (Jones \& Davis 2000, Ganichot 2002, Ramos et al. 2008, Tomasi et al. 2011). At the same time, grapes are being harvested with lower acidity and higher sugar levels, which is leading to higher alcohol content in wines (Duchêne \& Schneider 2005, Barbeau 2007). This study is a contribution to the analysis of climate change in the Loire Valley, France. We analyzed how the character and trends of regional climate during the vine-growing season have changed from 1960 to 2010. Furthermore, changes in berry composition for the 6 principal red and white varieties grown in the Loire Valley were studied, permitting improved understanding of the influence that climate change has had on the viticultural region of the Loire Valley.

\section{MATERIALS AND METHODS}

\subsection{Study region}

The Loire Valley wine region, situated at $47^{\circ} \mathrm{N}$ in the northwest of France, stretches between $1^{\circ} 33^{\prime} \mathrm{W}$ and $2^{\circ} 50^{\prime} \mathrm{E}$ from Nantes to Bourges (Fig. 1). The Loire Valley benefits from an oceanic influence to the west, which decreases towards the interior with a more continental influence to the east. With contrasting climate conditions, along with a rich pedological diversity, 69 different wine producing areas have been established in the Loire Valley region. The French AOP (Appellation d'Origine Protégée) body regulates wine in terms of quality and typicity, where the wine produced should express and have a strong relationship with its unique geographical environment, that is, with its unique 'terroir'. The Loire Valley wine region is the 4 th largest viticultural region in France with 70000 ha of vineyards, and it is the most important AOP white wine producer. It is cultivated with 14 white and red varieties, of which the white varieties represent $55 \%$ of the total surface area. The dominant white varieties are Melon (37\% of total white varieties), Chenin blanc (28\%) and Sauvignon blanc $(18 \%)$, whereas the dominant red varieties are Cabernet franc ( $46 \%$ of total red varieties), Grolleau noir $(25 \%)$ and Gamay (15\%). In the Muscadet wine region, Melon dominates the production of dry, light and fresh white wines. From Anjou to Touraine, Cabernet franc, Grolleau noir and Gamay are cultivated for the production of red and rosé wines while Chenin blanc is used for the production of sparkling, dry and liquor wines. Towards the east of the Loire Valley, in Sancerre, Sauvignon blanc is the dominant variety grown to produce dry white wines.

\subsection{Climate data}

The study was undertaken using the meteorological data from 7 weather stations situated in the Loire Valley (Fig. 1). The temperature and rainfall data were obtained from Météo France for the period of 1960 to 2010 (Table 1), allowing for analysis and characterization of long-term changes in climate. Although these 7 weather stations are not situated within the vineyards, they provide a good indication of the climate structure and trends in each region studied, namely Muscadet, Anjou, Saumurois, Bour- 
Table 1. Geographical positions of weather stations and climate data availability at each location. Data source: Météo France

\begin{tabular}{|c|c|c|c|c|}
\hline \multirow[t]{2}{*}{$\begin{array}{l}\text { Weather } \\
\text { station }\end{array}$} & \multirow[t]{2}{*}{$\begin{array}{l}\text { Altitude } \\
\text { (m) }\end{array}$} & \multirow[t]{2}{*}{ Location } & \multicolumn{2}{|c|}{$\begin{array}{l}\text { Period with available } \\
\text { climate data }\end{array}$} \\
\hline & & & Temperature & Rainfall \\
\hline Nantes & 26 & $47^{\circ} 09^{\prime} \mathrm{N}, 01^{\circ} 37^{\prime} \mathrm{W}$ & 1960-2010 & $1960-2010$ \\
\hline Angers & 50 & $47^{\circ} 29^{\prime} \mathrm{N}, 00^{\circ} 37^{\prime} \mathrm{W}$ & 1960-2010 & - \\
\hline $\begin{array}{l}\text { Beaulieu } \\
\text { sur Layon }\end{array}$ & 81 & $47^{\circ} 19^{\prime} \mathrm{N}, 00^{\circ} 36^{\prime} \mathrm{W}$ & - & $1960-2010$ \\
\hline Saumur & 69 & $47^{\circ} 15^{\prime} \mathrm{N}, 00^{\circ} 04^{\prime} \mathrm{W}$ & $1960-2010$ & $1960-2010$ \\
\hline Tours & 108 & $47^{\circ} 27^{\prime} \mathrm{N}, 00^{\circ} 44^{\prime} \mathrm{E}$ & $1960-2010$ & $1960-2010$ \\
\hline Romorantin & 83 & $47^{\circ} 19^{\prime} \mathrm{N}, 01^{\circ} 41^{\prime} \mathrm{E}$ & $1960-2010$ & - \\
\hline Bourges & 161 & $47^{\circ} 04^{\prime} \mathrm{N}, 02^{\circ} 22^{\prime} \mathrm{E}$ & $1960-2010$ & $1960-2010$ \\
\hline
\end{tabular}

(3) Number of days with $T_{x}$ between 25 and $30^{\circ} \mathrm{C}$ (no. $\mathrm{d} T_{\mathrm{x}} 25-30^{\circ} \mathrm{C}$ ) and no. $\mathrm{d} T_{\mathrm{x}}>$ $30^{\circ} \mathrm{C}$. Daytime $T_{\mathrm{x}}$ ranging from 25 to $30^{\circ} \mathrm{C}$ are critical for optimum grapevine photosynthesis (Carbonneau et al. 1992). However, prolonged days with $T_{\mathrm{x}}>30^{\circ} \mathrm{C}$ will induce plant stress.

The bioclimatic indices assist in defining a viticultural region in relation to its climate: its ability to produce grapes, the varieties that are the best adapted, as well as the precocity and lateness of the phenological stages (Asselin et al. 2001, Tonietto \& Carbonneau 2004). The bioclimatic indices

geuil, Chinon, Touraine and Sancerre (Fig. 1). For example, the mean growing season temperature (April to September) of Saumur from 1976 to 2010 was significantly correlated $\left(\mathrm{R}^{2}=0.97, \mathrm{p}<0.0001\right)$ with the mean growing season temperature of a weather station situated within the vineyards at Montreuil-Bellay, a commune of the AOP Saumur region.

Bonnefoy et al. (2010) studied the homogeneity of the temperature data acquired from these weather stations. They found a significant change point in the maximum temperatures in 1987 for these weather stations using the Pettitt test (Pettitt 1979). However, the minimum temperatures of Nantes and Angers indicated a significant change point in 1980, whereas the minimum temperatures of Tours, Romorantin and Bourges showed a change point in 1987. This significant thermal change point towards the end of the 1980's has also been identified in other viticultural regions in France (Briche et al. 2010, Madelin et al. 2010). Furthermore, it should be noted that the weather station of Tours, which opened in 1959, was repositioned $2 \mathrm{~km}$ outside of Tours in 1964. In analyzing the temperature data from Tours, Bonnefoy et al. (2010) identified a decrease in temperature during the 1960s. This decrease in temperature was not experienced by other weather stations in the Loire Valley, and it was concluded that the repositioning of the Tours station caused a discontinuity in the temperature data.

The daily mean, minimum and maximum temperatures were used to calculate several temperature variables and bioclimatic indices. The temperature variables calculated from 1960 to 2010 are

(1) Mean $\left(T_{\mathrm{m}}\right)$, minimum $\left(T_{\mathrm{n}}\right)$ and maximum $\left(T_{\mathrm{x}}\right)$ growing season temperatures (April to September).

(2) Seasonal $T_{\mathrm{m}}, T_{\mathrm{n}}$ and $T_{\mathrm{x}}$ where spring is defined as the period from March to May, summer from June to August, autumn from September to November and winter from December to February (Moisselin et al. 2002). calculated from the temperature data from 1960 to 2010 were

(1) The growing degree-days index (GDD), which is calculated as the sum of the daily mean temperatures $>10^{\circ} \mathrm{C}$ for the period April to October in the Northern Hemisphere (Table 2). The calculation uses a thermal base temperature of $10^{\circ} \mathrm{C}$, which is the minimum temperature necessary for grapevine physiological activity (Winkler et al. 1974). The interest in the GDD is that many studies have shown that the cumulated heat was significantly correlated with the phenological stages of the vine such as flowering, véraison and harvest (Tesic 2001, Van Leeuwen et al. 2008). However, the GDD index does not take into account an adjustment for the increasing day lengths at higher latitudes and as a result, it will underestimate the grape-producing potential of viticultural regions such as the Loire Valley (Tonietto \& Carbonneau 2004). The GDD index is divided into 7 climate classes: the 5 climate classes (Region I-V) originally determined by Winkler et al. (1974), and the upper and lower climate categories identified by Jones et al. (2010) (Table 2).

(2) The Huglin Index (HI) differs from the GDD index, as it is the sum of the $T_{\mathrm{m}}$ and $T_{\mathrm{x}}$ temperatures $>10^{\circ} \mathrm{C}$ from April to September in the Northern Hemisphere (Table 2; Huglin 1978). The HI gives greater weight to the maximum or daytime temperatures, which is when most vine development takes place (Jackson 2008). The calculation takes into account a coefficient of the latitude $(k)$, which is 1.05 for the Loire Valley, permitting the HI to be better correlated with vine growth and sugar concentration in the berries (Huglin 1978, Tonietto \& Carbonneau 2004). The HI is divided into 8 climate classes (Table 2).

(3) The cool night index (CI) is calculated as the average minimum temperature during the ripening month, which is September in the Northern Hemi- 
of Gamay allowed us to generate a representative set of data. From these reference vineyard plots, the berry composition data obtained on the date of the last analysis made prior to harvest were averaged, to obtain a single value for each variety, vintage and region. We recognize that the harvest date is not an accurate phenological stage and that the notion of determining maturity depends on important factors such as the style of wine wanted by the winemaker (Garcia de Cortazar-Atauri et al. 2010), which will influence berry composition. Lastly, the harvest dates studied corresponded to the date when the last berry composition analysis was made prior to harvest, and we assessed the trend in harvest dates for the 6 different varieties.

The above-mentioned climate variables, bioclimatic indices and berry composition data were analyzed using basic descriptive statistics to obtain the mean and standard deviation values of each parameter studied. Each parameter was plotted against a timescale in yr and a trend was determined. To evaluate the statistical significance of each observed trend, the p-value was determined using simple linear regression: using the Fisher's test with a $95 \%$ significance level. The non-parametric Friedman's test was also applied to identify whether there was a significant difference in the climate characteristics and trends between the weather stations. The p-value calculated by the Friedman's test allows one to reject the hypothesis that there is no significant difference between the weather stations. Finally, to study the influence that the changes in temperature had on berry composition, multiple linear regression was used to relate the berry composition (dependent) variables to the temperature and bioclimatic (independent) variables. However, an assessment was first made of the degree of co-linearity of each independent variable. It was argued that severe co-linearity existed when a temperature or bioclimatic variable had a tolerance value $<0.1$ and a variance inflation factor (VIF) value $>10$ (Quinn \& Keough 2002). The number of temperature and bioclimatic variables was therefore reduced using stepwise removal until all remaining variables, namely the GDD, CI, DTR, spring $T_{\mathrm{m}}$ and no. $\mathrm{d}$ $T_{\mathrm{x}} 25-30^{\circ} \mathrm{C}$, had a tolerance value $>0.2$ and a VIF value $<4$.
Table 3. Descriptive statistics of the mean $\left(T_{\mathrm{m}}\right)$, minimum $\left(T_{\mathrm{n}}\right)$ and maximum $\left(T_{\mathrm{x}}\right)$ temperatures of the Loire Valley during the growing season (April-September), from 1960-2010. All trends significant at the $95 \%$ level $(\mathrm{p}<0.05)$. Data source: Météo France

\begin{tabular}{|lcccccc|}
\hline $\begin{array}{l}\text { Tempera- } \\
\text { ture }\end{array}$ & $\begin{array}{c}\text { Mean } \\
\left({ }^{\circ} \mathrm{C}\right)\end{array}$ & $\begin{array}{c}\mathrm{SD} \\
\left({ }^{\circ} \mathrm{C}\right)\end{array}$ & $\begin{array}{c}\text { Trend } \\
\left(\mathrm{yr}^{-1}\right)\end{array}$ & $\begin{array}{c}\text { Total } \\
\text { trend }\end{array}$ & $\mathrm{R}^{2}$ & $\mathrm{p}$ \\
\hline$T_{\mathrm{m}}$ & 16.1 & 0.8 & +0.03 & +1.6 & 0.34 & $<0.0001$ \\
$T_{\mathrm{n}}$ & 10.6 & 0.7 & +0.03 & +1.3 & 0.32 & $<0.0001$ \\
$T_{\mathrm{x}}$ & 21.6 & 1.1 & +0.04 & +2.0 & 0.29 & $<0.0001$ \\
\hline
\end{tabular}

\section{RESULTS AND DISCUSSION}

\subsection{Climatic characteristics and trends}

\subsubsection{Temperature variables}

The daily $T_{\mathrm{m}}$ of the Loire Valley during the growing season (April to September) was $16.1^{\circ} \mathrm{C}$ for the period 1960 to 2010 (Table 3). Over this period, $T_{\mathrm{m}}$ $T_{\mathrm{n}}$ and $T_{\mathrm{x}}$ of the Loire Valley have significantly increased (Fig. 2).

The daily mean temperature increased by $1.6^{\circ} \mathrm{C}$, with $T_{\mathrm{n}}$ of the Loire Valley increasing by $1.3^{\circ} \mathrm{C}$ and $T_{\mathrm{x}}$ by $2.0^{\circ} \mathrm{C}$. As a result, the increase in mean temperature during the growing season in the Loire Valley has been driven by a faster rate of change in $T_{\mathrm{x}}$. Similar results where the $T_{\mathrm{x}}$ increased more significantly have been shown in the viticultural region of Priorat, Spain (Ramos et al. 2008). The 6 weather stations illustrated the same tendency with daily temperatures increasing significantly during the grow-

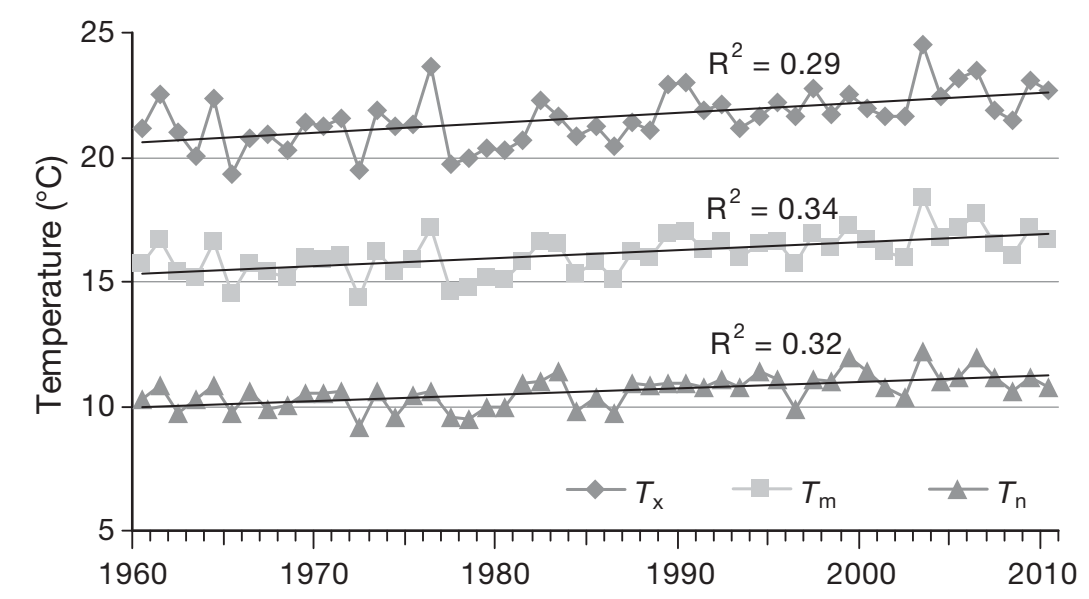

Fig. 2. Linear trends of daily mean $\left(T_{\mathrm{m}}\right)$, minimum $\left(T_{\mathrm{n}}\right)$ and maximum $\left(T_{\mathrm{x}}\right)$ temperatures in the Loire Valley wine region during the growing season (April-September) from 1960 to 2010. Average for 6 weather stations (Nantes, Angers, Saumur, Tours, Romorantin and Bourges). Data source: Météo France 
Table 4 . Descriptive statistics of the daily mean $\left(T_{\mathrm{m}}\right)$, minimum $\left(T_{\mathrm{n}}\right)$ and maximum $\left(T_{\mathrm{x}}\right)$ temperatures during the growing season (April-September) for 6 weather stations situated in the Loire Valley, from 1960-2010. All trends significant at the $95 \%$ level $(\mathrm{p}<0.05)$. Data source: Météo France

\begin{tabular}{|c|c|c|c|c|c|c|}
\hline & $\begin{array}{c}\text { Mean } \\
\left({ }^{\circ} \mathrm{C}\right)\end{array}$ & $\begin{array}{l}\text { SD } \\
\left({ }^{\circ} \mathrm{C}\right)\end{array}$ & $\begin{array}{c}\text { Trend } \\
\left(\mathrm{yr}^{-1}\right)\end{array}$ & $\begin{array}{l}\text { Total } \\
\text { trend }\end{array}$ & $\mathrm{R}^{2}$ & $\mathrm{p}$ \\
\hline \multicolumn{7}{|l|}{$T_{\mathrm{m}}$} \\
\hline Nantes & 16.2 & 0.8 & +0.03 & +1.4 & 0.24 & $<0.001$ \\
\hline Angers & 16.1 & 0.9 & +0.04 & +1.8 & 0.38 & $<0.0001$ \\
\hline Saumur & 16.7 & 0.9 & +0.04 & +1.8 & 0.35 & $<0.0001$ \\
\hline Tours & 15.9 & 0.9 & +0.03 & +1.7 & 0.34 & $<0.0001$ \\
\hline Romorantin & 15.5 & 0.9 & +0.03 & +1.3 & 0.25 & $<0.001$ \\
\hline Bourges & 16.1 & 0.9 & +0.04 & +1.8 & 0.36 & $<0.0001$ \\
\hline \multicolumn{7}{|l|}{$T_{\mathrm{n}}$} \\
\hline Nantes & 11.2 & 0.7 & +0.02 & +1.1 & 0.23 & $<0.001$ \\
\hline Angers & 10.9 & 0.7 & +0.03 & +1.5 & 0.42 & $<0.0001$ \\
\hline Saumur & 11.2 & 0.7 & +0.02 & +1.2 & 0.29 & $<0.0001$ \\
\hline Tours & 10.6 & 0.7 & +0.03 & +1.4 & 0.31 & $<0.0001$ \\
\hline Romorantin & 9.0 & 0.7 & +0.01 & +0.6 & 0.08 & 0.049 \\
\hline Bourges & 10.7 & 0.8 & +0.03 & +1.7 & 0.40 & $<0.0001$ \\
\hline \multicolumn{7}{|l|}{$T_{\mathrm{x}}$} \\
\hline Nantes & 21.2 & 1.1 & +0.03 & +1.6 & 0.20 & 0.001 \\
\hline Angers & 21.4 & 1.1 & +0.04 & +2.0 & 0.29 & $<0.0001$ \\
\hline Saumur & 22.3 & 1.3 & +0.05 & +2.4 & 0.32 & $<0.0001$ \\
\hline Tours & 21.2 & 1.1 & +0.04 & +2.0 & 0.29 & $<0.0001$ \\
\hline Romorantin & 21.9 & 1.1 & +0.04 & +2.0 & 0.28 & $<0.0001$ \\
\hline Bourges & 21.5 & 1.1 & +0.04 & +2.0 & 0.28 & $<0.0001$ \\
\hline
\end{tabular}

ing season (April to September) from 1960 to 2010 (Table 4). In all 6 locations, $T_{\mathrm{m}}$ trends have also been influenced by the more significant changes in $T_{\mathrm{x}}$. Over this study period, Saumur had the warmest daily $T_{\mathrm{m}}$ of $16.7^{\circ} \mathrm{C}$ (Table 4 ).

Given the change point in temperature, identified for the Loire Valley as during the 1980s (Bonnefoy et al. 2010), it is observed, for example, that the daily mean temperature of Saumur during the growing season increased from $16.2^{\circ} \mathrm{C}$ before the change point (1987) to $17.4^{\circ} \mathrm{C}$ after the change point. At Bourges, it has meant that the mean temperature evolved from $15.6^{\circ} \mathrm{C}$ before the change point (19601986) to $16.7^{\circ} \mathrm{C}$ after the change point $(1987-2010)$. Furthermore, an even more significant increase in temperature was observed at all 6 locations during the last 20 yr (results not shown). For example, 7 of the 10 warmest years recorded at Saumur during the growing season from 1960 to 2010 occurred during the past 15 yr. Consequently, for Saumur the last decade (2000-2009) was the warmest over the whole period of 1960 to 2010 , with a $T_{\mathrm{m}}$ of $17.6^{\circ} \mathrm{C}$.

The rate of warming has also not been consistent between the 6 locations. The mean daily temperature increased by $1.4^{\circ} \mathrm{C}$ in Nantes, $1.8^{\circ} \mathrm{C}$ in Angers, $1.8^{\circ} \mathrm{C}$ in Saumur, $1.7^{\circ} \mathrm{C}$ in Tours, $1.3^{\circ} \mathrm{C}$ in Romorantin and $1.8^{\circ} \mathrm{C}$ in Bourges between 1960 and 2010 (Table 4). Friedman's test showed that the changes in $T_{\mathrm{n}}$ and $T_{\mathrm{x}}$ are significantly different between stations. The changes in $T_{\mathrm{n}}$ at Nantes and Saumur are significantly different from those of Tours, Romorantin and Bourges $(p<0.0001)$, while $T_{\mathrm{x}}$ at Saumur and Romorantin are significantly different from $T_{\mathrm{x}}$ at Nantes, Angers and Tours $(\mathrm{p}<0.0001)$. Bonnefoy et al. (2010) explained that these variations in temperature observed within the Loire Valley are due to factors such as the distance of the weather stations from the Atlantic Ocean or the Loire River, their latitudinal position and the influence of topography on the local area. As studies have illustrated for other viticultural regions in France (Laget et al. 2008, Madelin et al. 2010), the rate of warming has also not been uniform over the period from 1960 to 2010

Because of variability of air temperature during the year and the growing season, seasonal mean temperatures were calculated. Spring and especially summer $T_{\mathrm{m}}$ increased significantly at all 6 locations (Table 5), in comparison with winter and autumn temperatures that did not significantly increase at all sites (results not shown). The rate of warming during spring increased the greatest at Saumur, by $1.8^{\circ} \mathrm{C}$, whereas the greatest increase during the summer of $2.4^{\circ} \mathrm{C}$ occurred at Bourges (Table 5).

The rate of warming during the spring and summer was also influenced by greater increases in maximum temperatures (results not shown). Results

Table 5. Descriptive statistics of spring and summer daily mean temperatures $\left(T_{\mathrm{m}}\right)$ during the growing season (AprilSeptember) for 6 weather stations situated in the Loire Valley, from 1960-2010. All trends significant at the 95\% level $(\mathrm{p}<0.05)$. Data source: Météo France

\begin{tabular}{|lcccccc|}
\hline & $\begin{array}{c}\text { Mean } \\
\left({ }^{\circ} \mathrm{C}\right)\end{array}$ & $\begin{array}{c}\mathrm{SD} \\
\left({ }^{\circ} \mathrm{C}\right)\end{array}$ & $\begin{array}{c}\text { Trend } \\
\left(\mathrm{yr}^{-1}\right)\end{array}$ & $\begin{array}{c}\text { Total } \\
\text { trend }\end{array}$ & $\mathrm{R}^{2}$ & $\mathrm{p}$ \\
\hline Spring $\boldsymbol{T}_{\mathrm{m}}$ & & & & & & \\
Nantes & 11.1 & 0.9 & +0.03 & +1.4 & 0.24 & $<0.001$ \\
Angers & 10.9 & 0.9 & +0.02 & +1.7 & 0.20 & $<0.001$ \\
Saumur & 11.4 & 1.0 & +0.04 & +1.8 & 0.32 & $<0.0001$ \\
Tours & 10.5 & 0.9 & +0.03 & +1.6 & 0.26 & $<0.001$ \\
Romorantin & 10.2 & 0.9 & +0.02 & +1.2 & 0.19 & 0.002 \\
Bourges & 10.5 & 1.0 & +0.03 & +1.7 & 0.27 & $<0.001$ \\
Summer $\boldsymbol{T}_{\mathrm{m}}$ & & & & & & \\
Nantes & 18.5 & 1.1 & +0.03 & +1.6 & 0.17 & 0.003 \\
Angers & 18.5 & 1.2 & +0.03 & +2.1 & 0.28 & $<0.0001$ \\
Saumur & 19.3 & 1.2 & +0.04 & +2.1 & 0.28 & $<0.0001$ \\
Tours & 18.5 & 1.1 & +0.04 & +2.1 & 0.30 & $<0.0001$ \\
Romorantin & 18.0 & 1.0 & +0.04 & +1.8 & 0.28 & $<0.0001$ \\
Bourges & 18.8 & 1.2 & +0.05 & +2.4 & 0.36 & $<0.0001$ \\
\hline
\end{tabular}


showed therefore that the most significant warming has taken place during the growing season and especially during the period between flowering and véraison (summer period). Jones \& Davis (2000) showed that for 2 red grape varieties, the temperature in Bordeaux during the period between flowering and véraison has a significant influence on berry composition. It is therefore likely that these major increases in temperature during the summer in the Loire Valley will also have important influences on berry composition and hence on wine quality in the region.

Given the significant increases in $T_{\mathrm{x}}$ during the growing season, the $T_{\mathrm{x}} 25-30^{\circ} \mathrm{C}$ and no. $\mathrm{d} T_{\mathrm{x}}>30^{\circ} \mathrm{C}$ during the growing season have also significantly increased at all 6 locations between 1960 and 2010 (Table 6).

During the summer, daytime $T_{\mathrm{x}}$ ranging from 25 to $30^{\circ} \mathrm{C}$ is critical for optimum grapevine photosynthesis (Carbonneau et al. 1992). Consequently, a higher number of days with optimum temperatures during the growing season will favor grapevine development and the sugar concentration in grapes, as sugar accumulation is related to the photosynthetic activity of the vine during maturation (Jackson 2008). However, prolonged days with maximum temperatures $>30^{\circ} \mathrm{C}$ will induce plant stress and result in a decrease in the photosynthetic activity, while at $40^{\circ} \mathrm{C}$ photosynthesis is completely inhibited (RibéreauGayon et al. 2006, Jackson 2008).

Table 6. Descriptive statistics of no. of days with maximum temperatures between $25-30^{\circ} \mathrm{C}$ and with $T_{\mathrm{x}}>30^{\circ} \mathrm{C}$ during the growing season (April-September) for 6 weather stations situated in the Loire Valley, from 1960-2010. All trends significant at the $95 \%$ level $(\mathrm{p}<0.05)$. Data source: Météo France

\begin{tabular}{|lrrrrrr|}
\hline & $\begin{array}{r}\text { Mean } \\
\left({ }^{\circ} \mathrm{C}\right)\end{array}$ & $\begin{array}{r}\mathrm{SD} \\
\left({ }^{\circ} \mathrm{C}\right)\end{array}$ & $\begin{array}{r}\text { Trend } \\
\left(\mathrm{yr}^{-1}\right)\end{array}$ & $\begin{array}{r}\text { Total } \\
\text { trend }\end{array}$ & $\mathrm{R}^{2}$ & $\mathrm{p}$ \\
\hline $\mathbf{2 5 - 3 0} \mathbf{C}$ & & & & & & \\
Nantes & 31.5 & 11.3 & +0.21 & +10.5 & 0.08 & 0.048 \\
Angers & 35.2 & 10.8 & +0.23 & +11.5 & 0.10 & 0.023 \\
Saumur & 45.6 & 11.1 & +0.27 & +13.5 & 0.13 & 0.008 \\
Tours & 35.2 & 10.2 & +0.31 & +15.5 & 0.20 & 0.001 \\
Romorantin & 40.5 & 10.5 & +0.29 & +14.5 & 0.16 & 0.003 \\
Bourges & 38.4 & 9.4 & +0.30 & +15.0 & 0.22 & $<0.001$ \\
$>\mathbf{3 0}{ }^{\circ} \mathbf{C}$ & & & & & & \\
Nantes & 8.1 & 6.4 & +0.16 & +8.0 & 0.14 & 0.008 \\
Angers & 9.8 & 7.6 & +0.19 & +9.5 & 0.21 & $<0.001$ \\
Saumur & 13.7 & 9.5 & +0.34 & +17.0 & 0.28 & $<0.0001$ \\
Tours & 9.4 & 7.4 & +0.18 & +9.0 & 0.13 & 0.008 \\
Romorantin & 12.5 & 8.1 & +0.24 & +12.0 & 0.19 & 0.001 \\
Bourges & 12.4 & 7.7 & +0.19 & +9.5 & 0.13 & 0.008 \\
\hline
\end{tabular}

\subsubsection{Bioclimatic indices}

Growing degree-days index (GDD). The GDD has significantly increased at all 6 locations in the Loire Valley, with Saumur displaying the greatest increase of 360 GDD, from 1960 to 2010 (Table 7). These increases in GDD imply that all 6 locations have evolved from Region I to II, except for Romorantin, which remained in Region I (Table 2).

Studies have illustrated that the GDD values were well correlated with the phenological stages of the vine (Tesic 2001, Van Leeuwen et al. 2008). Higher values in GDD will therefore likely lead to earlier flowering, véraison and harvest dates. Our results illustrated that the trend in GDD for Saumur and Tours was significantly correlated with earlier harvest dates for Cabernet franc, cultivated in the regions of Chinon and Bourgueil and for Chenin blanc, cultivated in the region of Touraine, from 1970 to 2010 (Table 8).

In the Chinon and Bourgueil regions, the harvest date for Cabernet franc advanced significantly by 15 and $16 \mathrm{~d}$ respectively, whereas the harvest date for Chenin blanc advanced by $16 \mathrm{~d}$ at Touraine (Table 9). As shown in other studies in France, we

Table 7. Descriptive statistics of the growing degree-days index (GDD) for 6 weather stations situated in the Loire Valley, from 1960-2010. All trends significant at the 95\% level $(\mathrm{p}<0.05)$

\begin{tabular}{|lccccccc|}
\hline Station & $\begin{array}{c}\text { Mean } \\
\text { GDD }\end{array}$ & SD & $\begin{array}{c}\text { Trend } \\
\left(\mathrm{yr}^{-1}\right)\end{array}$ & $\begin{array}{c}\text { Total } \\
\text { trend }\end{array}$ & $\mathrm{R}^{2}$ & $\mathrm{p}$ \\
\hline Nantes & 1270 & 161 & +5.36 & +268 & 0.25 & $<0.001$ \\
Angers & 1258 & 165 & +6.91 & +345 & 0.39 & $<0.0001$ \\
Saumur & 1367 & 177 & +7.20 & +360 & 0.36 & $<0.0001$ \\
Tours & 1221 & 160 & +6.47 & +324 & 0.36 & $<0.0001$ \\
Romorantin & 1129 & 144 & +5.01 & +251 & 0.27 & $<0.0001$ \\
Bourges & 1255 & 168 & +7.02 & +351 & 0.39 & $<0.0001$ \\
\hline
\end{tabular}

Table 8. Correlations between growing degree-days (GDD) at Saumur and Tours and the near-harvest dates of Chenin Blanc cultivated in the region of Touraine, and Cabernet Franc cultivated in the regions of Chinon and Bourgueil, from 1970-2010. All trends significant at the 95\% level $(\mathrm{p}<0.05)$

\begin{tabular}{|lccc|}
\hline \multirow{2}{*}{ Region } & \multirow{2}{*}{ Grape variety } & \multicolumn{2}{c|}{ Correlation } \\
& (number of plots) & GDD & GDD \\
& Saumur & Tours \\
\hline Touraine & Chenin blanc (2) & -0.76 & -0.77 \\
Bourgueil & Cabernet franc (5) & -0.80 & -0.77 \\
Chinon & Cabernet franc (5) & -0.83 & -0.81 \\
\hline
\end{tabular}



in the region of Touraine and Cabernet franc cultivated in the regions of Chinon and Bourgueil, from 1970-2010. All trends significant at the 95\% level $(\mathrm{p}<0.05)$. Data source: Laboratoire de Touraine

\begin{tabular}{|lcccccccc|}
\hline Region & $\begin{array}{c}\text { Variety } \\
\text { (number } \\
\text { of plots) }\end{array}$ & $\begin{array}{c}\text { Mean } \\
\text { (date) }\end{array}$ & $\begin{array}{c}\text { SD } \\
(\mathrm{d})\end{array}$ & $\begin{array}{c}\text { Trend } \\
\mathrm{yr}^{-1}\end{array}$ & $\begin{array}{c}\text { Total } \\
\text { trend }\end{array}$ & $\mathrm{R}^{2}$ & $\mathrm{p}$ \\
\hline Touraine & Chenin blanc (2) & 30 Sep & 9 & -0.42 & -16.6 & 0.34 & $<0.0001$ \\
Bourgueil & Cabernet franc (5) & 29 Sep & 9 & -0.41 & -16.4 & 0.30 & 0.001 \\
Chinon & Cabernet franc (5) & 2 Oct & 9 & -0.38 & -15.0 & 0.27 & 0.001 \\
\hline
\end{tabular}

Table 9. Descriptive statistics of the harvest dates of Chenin blanc cultivated

tional Bordeaux wine-growing region (Tonietto \& Carbonneau 2004).

Fig. 3 shows the significantly increasing trend of the HI at Saumur. Over the past decade, the HI of certain years at Saumur, such as in 2003, were even situated in a warm temperate climate, which is equivalent to the climate of Montpellier, South of France, $30 \mathrm{yr}$ ago (Vaudour 2003, Tonietto \& Carbonneau 2004). Warmer climate categories such as a temperate climate will enable varieties such as Cabernet Sauvignon and Merlot to reach optimum maturity, whereas a warm temperate climate category will enable varieties that are not currently grown in the Loire Valley, such as Syrah and Grenache, to reach maturity (Tonietto \& Carbonneau 2004).

The 2003 vintage was characterized by a warm temperate climate at Saumur enabling, during this season, 2 late ripening red varieties to reach maturity. They were Syrah, which is typically grown in the south of France, and Tempranillo, which is traditionally cultivated in Spain. INRA Angers grow these 2 varieties in experimental plots that are situated at Montreuil Bellay. The Syrah grapes were harvested

Table 10. Descriptive statistics of the Huglin Index (HI) for 6 weather stations situated in the Loire Valley, from 1960-2010. All trends significant at the $95 \%$ level ( $<<0.05)$. Data source: Météo France logical stages that will allow varieties to reach an optimum maturity, especially late ripening varieties such as Cabernet franc and Cabernet Sauvignon. Warmer temperatures will therefore favour grapevine growing in the Loire Valley and will influence the berry composition. Earlier phenological stages will allow these late ripening varieties to accumulate greater amounts of sugar, and to have optimum titratable acidity concentrations and more ripened berry flavors (Barbeau 2007). However, early ripening varieties, such as Gamay or Melon, will ripen in warmer than ideal environmental conditions. This will likely lead to phenological stages appearing too early, causing sugars to accumulate too soon, leading to a rapid decrease in titratable acidity given the effect of high temperatures on the rate of respiration and influencing the synthesis of berry flavors (Coombe 1987, Ribéreau-Gayon et al. 2006).

The Huglin Index $(H I)$. The HI has significantly increased from 1960 to 2010 at all 6 locations (Table 10). These significant increases in the HI mean that all 6 locations have shifted from a cool climate, which used to characterize the Loire Valley, to a temperate climate (Table 2), which characterizes the tradi-

\begin{tabular}{|lccccccc|}
\hline Station & Mean HI & SD & $\begin{array}{c}\text { Trend } \\
\left(\mathrm{yr}^{-1}\right)\end{array}$ & $\begin{array}{c}\text { Total } \\
\text { trend }\end{array}$ & $\mathrm{R}^{2}$ & $\mathrm{p}$ \\
\hline Nantes & 1680 & 180 & +5.63 & +282 & 0.22 & 0.001 \\
Angers & 1698 & 185 & +7.12 & +356 & 0.33 & $<0.0001$ \\
Saumur & 1840 & 205 & +7.96 & +398 & 0.33 & $<0.0001$ \\
Tours & 1666 & 181 & +6.79 & +340 & 0.31 & $<0.0001$ \\
Romorantin & 1681 & 176 & +6.18 & +309 & 0.27 & $<0.0001$ \\
Bourges & 1712 & 187 & +7.11 & +356 & 0.32 & $<0.0001$ \\
\hline
\end{tabular}

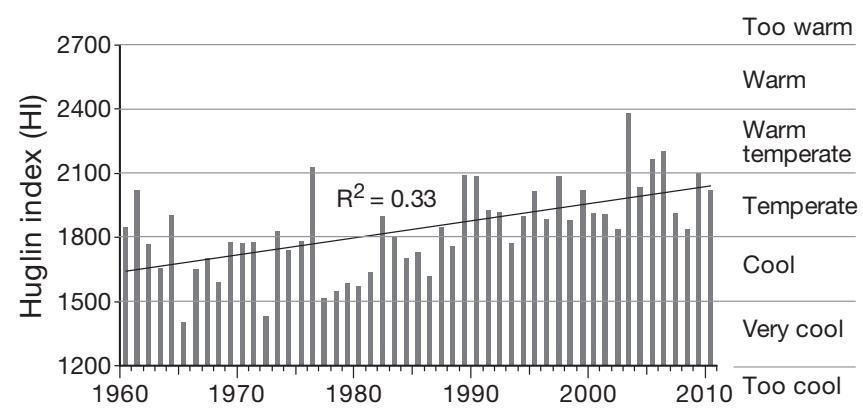

Fig. 3. Linear trend of the Huglin Index (HI) at Saumur from 1960 to 2010. Data source: Météo France 
at a sugar concentration of $205 \mathrm{~g} \mathrm{l}^{-1}\left(12.2^{\circ}\right.$ potential alcohol) and a titratable acidity of $4.1 \mathrm{~g} \mathrm{l}^{-1}$. The Tempranillo grapes had a sugar concentration of $192 \mathrm{~g} \mathrm{l}^{-1}$ (11.4 ${ }^{\circ}$ potential alcohol) and a titratable acidity of $3.5 \mathrm{~g} \mathrm{l}^{-1}$ (G. Barbeau pers. com.). Therefore, as temperatures are predicted to increase during the 21st century in France (Brisson \& Levrault 2010), late ripening grape varieties will likely be able to reach maturity, as already observed in 2003.

Cool night index $(C I)$. The CI has significantly increased at Angers and Bourges from 1960 to 2010 (Table 11). It increased by $0.9^{\circ} \mathrm{C}$ at Angers and by $1.1^{\circ} \mathrm{C}$ at Bourges, which means that for both sites the $\mathrm{CI}$ evolved from very cool nights $\left(<12^{\circ} \mathrm{C}\right)$ to cool nights $\left(12\right.$ to $\left.14^{\circ} \mathrm{C}\right)$. In general, warm night temperatures during ripening have the tendency to lead to a loss in aromas, and in red varieties, to a loss in grape color (Carey et al. 2008, Jackson 2008). However, for the Loire Valley, we observed that night conditions were still relatively cool and that minimum temperatures during ripening have not increased as much as maximum temperatures.

Diurnal temperature range (DTR). The diurnal temperature range during the ripening period (August to September) displayed significant increases

Table 11. Descriptive statistics of the cool night index (CI) for 6 weather stations situated in the Loire Valley, from 1960 to 2010 (15 August-30 September). Bold: significant trends at $95 \%$ level $(\mathrm{p}<0.05)$. Data source: Météo France

\begin{tabular}{|lrrrrrc|}
\hline Station & $\begin{array}{r}\text { Mean } \\
\mathrm{CI}\left({ }^{\circ} \mathrm{C}\right)\end{array}$ & $\begin{array}{r}\mathrm{SD} \\
\left({ }^{\circ} \mathrm{C}\right)\end{array}$ & $\begin{array}{c}\text { Trend } \\
\left(\mathrm{yr}^{-1}\right)\end{array}$ & $\begin{array}{r}\text { Total } \\
\text { trend }\end{array}$ & $\mathrm{R}^{2}$ & $\mathrm{p}$ \\
\hline Nantes & 12.4 & 1.0 & +0.01 & +0.6 & 0.03 & 0.241 \\
Angers & 12.0 & 1.0 & $\mathbf{+ 0 . 0 2}$ & $\mathbf{+ 0 . 9}$ & 0.08 & $\mathbf{0 . 0 4 8}$ \\
Saumur & 12.1 & 1.1 & +0.01 & +0.6 & 0.03 & 0.268 \\
Tours & 11.7 & 1.0 & +0.02 & +0.8 & 0.05 & 0.117 \\
Romorantin & 9.6 & 1.2 & 0.00 & 0.0 & 0.00 & 0.780 \\
Bourges & 11.8 & 1.0 & $\mathbf{+ 0 . 0 2}$ & $\mathbf{+ 1 . 1}$ & 0.10 & $\mathbf{0 . 0 2 6}$ \\
\hline
\end{tabular}

Table 12. Descriptive statistics of the diurnal Temperature Range (DTR) for 6 weather stations situated in the Loire Valley, from 1960-2010 (August-September). Bold: significant trends at $95 \%$ level $(\mathrm{p}<0.05)$. Data source: Météo France

\begin{tabular}{|lcrrrcc|}
\hline Station & $\begin{array}{c}\text { Mean } \\
\mathrm{DTR}\left({ }^{\circ} \mathrm{C}\right)\end{array}$ & $\begin{array}{c}\mathrm{SD} \\
\left({ }^{\circ} \mathrm{C}\right)\end{array}$ & $\begin{array}{r}\text { Trend } \\
\left(\mathrm{yr}^{-1}\right)\end{array}$ & $\begin{array}{r}\text { Total } \\
\text { trend }\end{array}$ & $\mathrm{R}^{2}$ & $\mathrm{p}$ \\
\hline Nantes & 10.4 & 1.0 & $\mathbf{+ 0 . 0 2}$ & $\mathbf{+ 1 . 0}$ & 0.09 & $\mathbf{0 . 0 3 2}$ \\
Angers & 10.9 & 1.0 & 0.00 & 0.0 & 0.02 & 0.244 \\
Saumur & 11.5 & 1.1 & $\mathbf{+ 0 . 0 3}$ & $\mathbf{+ 1 . 5}$ & 0.17 & $\mathbf{0 . 0 0 3}$ \\
Tours & 11.0 & 1.0 & $\mathbf{+ 0 . 0 2}$ & $\mathbf{+ 0 . 9}$ & 0.06 & 0.074 \\
Romorantin & 13.5 & 1.5 & $\mathbf{+ 0 . 0 3}$ & $\mathbf{+ 1 . 7}$ & 0.11 & $\mathbf{0 . 0 1 8}$ \\
Bourges & 11.1 & 1.1 & 0.00 & 0.0 & 0.00 & 0.755 \\
\hline
\end{tabular}

over the study period. It increased by $1.0^{\circ} \mathrm{C}$ at Nantes, $1.5^{\circ} \mathrm{C}$ at Saumur and by $1.7^{\circ} \mathrm{C}$ at Romorantin from 1960 to 2010 (Table 12). These significant increases in DTR are due to maximum temperatures increasing more significantly than minimum temperatures during the ripening period (results not shown). Studies have illustrated that the thermal amplitude during ripening has significant effects on the accumulation of berry components (Coombe 1987, Carbonneau et al. 1992, Ribéreau-Gayon et al. 2006). These studies showed that the synthesis of anthocyanins is favored by a strong difference between the diurnal and nocturnal temperatures. Ramos et al. (2008) illustrated that greater DTR values were correlated with higher quality red wine. The greater DTR values shown for Saumur, where Cabernet franc is mainly grown, will be favorable for the production of quality red wine.

\subsubsection{Rainfall variables}

During the growing season, it is observed that Beaulieu sur Layon had the lowest mean rainfall with $262.1 \mathrm{~mm}$ from 1960 to 2010, whereas Bourges had the highest with $375.2 \mathrm{~mm}$ (Table 13). In all 5 locations, no significant evolution in rainfall was observed for the 3 seasonal periods studied, namely

Table 13. Statistics of mean rainfall during 3 seasonal periods (Jan-Sep, Apr-Sep: growing season, and Jun-Aug: summer) studied for 5 weather stations in the Loire Valley from 1960-2010. Data source: Météo France

\begin{tabular}{|lrrrrrc|}
\hline & $\begin{array}{c}\text { Mean } \\
(\mathrm{mm})\end{array}$ & $\begin{array}{c}\mathrm{SD} \\
(\mathrm{mm})\end{array}$ & $\begin{array}{c}\text { Trend } \\
\left(\mathrm{yr}^{-1}\right)\end{array}$ & $\begin{array}{r}\text { Total } \\
\text { trend }\end{array}$ & $\mathrm{R}^{2}$ & $\mathrm{p}$ \\
\hline Jan-Sep & & & & & & \\
Nantes & 537.7 & 106.9 & -0.11 & -5.5 & 0.00 & 0.915 \\
$\begin{array}{l}\text { Beaulieu } \\
\text { sur Layon }\end{array}$ & 419.0 & 93.0 & -0.10 & -5.0 & 0.00 & 0.907 \\
Saumur & 411.5 & 78.8 & +0.77 & +38.5 & 0.02 & 0.311 \\
Tours & 487.6 & 103.0 & -0.43 & -21.5 & 0.00 & 0.662 \\
Bourges & 544.9 & 107.3 & -0.05 & -2.5 & 0.00 & 0.963 \\
Apr-Sep & & & & & & \\
Nantes & 319.6 & 80.5 & 0.00 & 0.0 & 0.00 & 0.993 \\
Beaulieu & 262.1 & 80.4 & -0.20 & -10.0 & 0.00 & 0.805 \\
$\quad \begin{array}{l}\text { sur Layon } \\
\text { Saumur }\end{array}$ & 265.4 & 68.9 & +0.51 & +25.5 & 0.01 & 0.441 \\
Tours & 313.1 & 82.4 & -0.45 & -22.5 & 0.01 & 0.572 \\
Bourges & 375.2 & 83.6 & +0.48 & -24.0 & 0.01 & 0.554 \\
Jun-Aug & & & & & & \\
Nantes & 136.8 & 49.7 & -0.16 & -8.0 & 0.00 & 0.732 \\
Beaulieu & 117.3 & 55.7 & -0.40 & -20.0 & 0.01 & 0.466 \\
$\quad$ sur Layon & & & & & & \\
Saumur & 118.6 & 42.7 & 0.00 & 0.0 & 0.00 & 0.993 \\
Tours & 143.7 & 60.2 & -0.31 & -15.5 & 0.01 & 0.591 \\
Bourges & 177.7 & 62.5 & +0.45 & -22.5 & 0.01 & 0.458 \\
\hline
\end{tabular}


from January to September, April to September (growing season) and from June to August (summer). However, we noted a high variability from year to year, which could be the reason for no significant evolution. The 2 rainfall indices calculated from the daily rainfall data at Beaulieu sur Layon showed no significant trend from 1960 to 2010 (results not shown). Therefore, the number of days where the rainfall was $<1 \mathrm{~mm}$ and where it was $\geq 10 \mathrm{~mm}$ have not changed over the 2 periods studied (the growing season and summer periods). According to our results, we observed that the rainfall has not changed significantly in all 5 locations from 1960 to 2010.

\subsection{Evolution of berry composition}

The 6 main white and red varieties cultivated in the Loire Valley have shown a significant change in their berry composition (Table 14). Each variety displayed an increase in sugar concentration and a decrease in titratable acidity, except the titratable acidity concentration of Melon, grown in the Muscadet region, and Sauvignon blanc, grown in the Anjou region, which did not change significantly.

For Chenin blanc, the concentration of sugar increased by 38.2, 38.0 and $39.4 \mathrm{~g} \mathrm{l}^{-1}$ in Anjou, Saumurois and Touraine, respectively, from 1981 to

Table 14. Descriptive statistics of the concentrations of sugar and titratable acidity for the 3 principal red and white grape varieties cultivated in the Loire Valley. Bold: statistically significant trends at $95 \%$ level $(p<0.05)$. Data sources-white: CA 44, ATV 49, Laboratoire de Touraine 37, SICAVAC 18; red: ATV 49, Laboratoire de Touraine 37

\begin{tabular}{|c|c|c|c|c|c|c|c|c|}
\hline Grape variety & Region & $\begin{array}{l}\text { No. of } \\
\text { plots }\end{array}$ & $\begin{array}{l}\text { Mean } \\
\left(\mathrm{g} \mathrm{l}^{-1}\right)\end{array}$ & $\begin{array}{c}\mathrm{SD} \\
\left(\mathrm{g} \mathrm{l}^{-1}\right)\end{array}$ & $\begin{array}{c}\text { Trend } \\
\left(\mathrm{yr}^{-1}\right)\end{array}$ & $\begin{array}{l}\text { Total } \\
\text { trend }\end{array}$ & $\mathrm{R}^{2}$ & $\mathrm{p}$ \\
\hline \multicolumn{9}{|l|}{ Sugar } \\
\hline \multicolumn{9}{|l|}{ White } \\
\hline Melon & Muscadet & $20^{\mathrm{f}}$ & 174.9 & 14.8 & +1.05 & +24.1 & 0.25 & 0.013 \\
\hline \multirow[t]{3}{*}{ Chenin blanc } & Anjou & $8^{e}$ & 197.2 & 18.7 & +1.32 & +38.2 & 0.39 & $<0.001$ \\
\hline & Saumurois & $2^{\mathrm{e}}$ & 187.4 & 18.4 & +1.31 & +38.2 & 0.40 & $<0.001$ \\
\hline & Touraine & $9^{b}$ & 192.7 & 20.9 & +1.55 & +48.1 & 0.49 & $<0.0001$ \\
\hline \multirow[t]{3}{*}{ Sauvignon blanc } & Anjou & $2^{\mathrm{e}}$ & 188.1 & 16.2 & +1.18 & +38.9 & 0.41 & $<0.001$ \\
\hline & Touraine & $3^{\mathrm{e}}$ & 188.2 & 22.6 & +2.01 & +58.3 & 0.62 & $<0.0001$ \\
\hline & Sancerre & $1^{\mathrm{c}}$ & 200.0 & 21.1 & +1.57 & +45.6 & 0.43 & $<0.0001$ \\
\hline \multicolumn{9}{|l|}{ Red } \\
\hline \multirow[t]{2}{*}{ Gamay } & Anjou & $6^{\mathrm{e}}$ & 184.0 & 14.7 & +0.87 & +25.0 & 0.27 & 0.003 \\
\hline & Touraine & $5^{\mathrm{d}}$ & 189.7 & 18.7 & +1.57 & +47.2 & 0.59 & $<0.0001$ \\
\hline \multirow[t]{2}{*}{ Grolleau noir } & Anjou & $5^{\mathrm{e}}$ & 168.1 & 16.4 & +1.26 & +36.5 & 0.46 & $<0.0001$ \\
\hline & Touraine & $4^{\mathrm{d}}$ & 171.2 & 21.6 & +1.78 & +53.5 & 0.56 & $<0.0001$ \\
\hline \multirow[t]{4}{*}{ Cabernet franc } & Anjou & $10^{\mathrm{e}}$ & 184.3 & 19.6 & +1.61 & +46.6 & 0.52 & $<0.0001$ \\
\hline & Saumurois & $4^{\mathrm{e}}$ & 186.9 & 20.8 & +1.88 & +54.4 & 0.63 & $<0.0001$ \\
\hline & Bourgueil & $5^{\mathrm{a}}$ & 185.7 & 17.6 & +1.03 & +41.0 & 0.49 & $<0.0001$ \\
\hline & Chinon & $5^{\mathrm{a}}$ & 187.4 & 20.4 & +1.30 & +51.8 & 0.58 & $<0.0001$ \\
\hline \multicolumn{9}{|l|}{ Titratable acidity } \\
\hline \multicolumn{9}{|l|}{ White } \\
\hline Melon & Muscadet & $20^{\mathrm{f}}$ & 5.9 & 0.9 & -0.03 & -0.7 & 0.05 & 0.312 \\
\hline \multirow[t]{3}{*}{ Chenin blanc } & Anjou & $8^{\mathrm{e}}$ & 6.5 & 1.2 & -0.07 & -2.0 & 0.27 & 0.003 \\
\hline & Saumurois & $2^{\mathrm{e}}$ & 7.0 & 1.4 & -0.10 & -3.1 & 0.41 & $<0.001$ \\
\hline & Touraine & $9^{b}$ & 6.4 & 1.7 & -1.12 & -3.7 & 0.45 & $<0.0001$ \\
\hline \multirow[t]{3}{*}{ Sauvignon blanc } & Anjou & $2^{\mathrm{e}}$ & 5.8 & 0.9 & -0.03 & -1.0 & 0.09 & 0.113 \\
\hline & Touraine & $3^{\mathrm{e}}$ & 6.0 & 1.4 & -0.10 & -2.8 & 0.39 & $<0.001$ \\
\hline & Sancerre & $1^{\mathrm{c}}$ & 6.1 & 1.1 & -0.06 & -2.7 & 0.25 & 0.005 \\
\hline \multicolumn{9}{|l|}{ Red } \\
\hline \multirow[t]{2}{*}{ Gamay } & Anjou & $6^{\mathrm{e}}$ & 6.1 & 1.2 & -0.04 & -1.2 & 0.23 & 0.007 \\
\hline & Touraine & $5^{\mathrm{d}}$ & 6.2 & 0.9 & -0.08 & -2.4 & 0.57 & $<0.0001$ \\
\hline \multirow[t]{2}{*}{ Grolleau noir } & Anjou & $5^{\mathrm{e}}$ & 6.1 & 1.2 & -0.07 & -2.0 & 0.26 & 0.004 \\
\hline & Touraine & $4^{\mathrm{d}}$ & 5.7 & 1.5 & -0.12 & -3.5 & 0.50 & $<0.0001$ \\
\hline \multirow[t]{4}{*}{ Cabernet franc } & Anjou & $10^{\mathrm{e}}$ & 6.0 & 1.2 & -0.08 & -2.2 & 0.33 & 0.001 \\
\hline & Saumurois & $4^{\mathrm{e}}$ & 5.7 & 1.0 & -0.07 & -2.0 & 0.36 & $<0.001$ \\
\hline & Bourgueil & $5^{\mathrm{a}}$ & 5.5 & 1.4 & -0.07 & -2.8 & 0.37 & $<0.0001$ \\
\hline & Chinon & $5^{\mathrm{a}}$ & 5.4 & 1.2 & -0.07 & -2.7 & 0.42 & $<0.0001$ \\
\hline
\end{tabular}


was greater than the autumn and winter temperatures at all 6 locations. The results illustrate that the no. d $25-30^{\circ} \mathrm{C}$ and the no. d $T_{\mathrm{x}}>30^{\circ} \mathrm{C}$ increased significantly between 1960 and 2010 . The significant increases in GDD have resulted in harvest dates advancing by 2 wk on average. The trend in HI illustrated that the 6 locations situated in the Loire Valley have evolved from a cool climate to a temperate climate, which means late ripening varieties are more likely to reach maturity. The 6 main varieties cultivated in the Loire Valley have reacted to these climate changes, as levels of titratable acidity were lower and sugar levels were higher at harvest, which has led to higher potential alcohol concentrations. The trends in sugar and titratable acidity concentrations for the 6 varieties were significantly correlated with temperature variables and bioclimatic indices. Results indicate that the observed increase in temperature has significantly influenced the berry composition of the main grape varieties cultivated in the Loire Valley.

Acknowledgements. This research falls under the international research project 'ANR-TERVICLIM' of CNRS (LETG UMR 6554). We thank all the organizations that made available their berry composition data. The data were acquired from the 'Chambre d'Agriculture 44' (CA 44) for the region of Muscadet, the 'Association Technique Viticole 49' (ATV) for the regions of Anjou and Saumur, the 'Laboratoire de Touraine' for the regions of Touraine, Chinon and Bourgueil, and 'SICAVAC' for the region of Sancerre. We thank Météo France for the climate data that were provided for the 7 weather stations and also A. Sturman, V. Bonnardot and C. Coulon for their comments.

\section{LITERATURE CITED}

Asselin C, Barbeau G, Morlat R (2001) Approche de la composante climatique à diverses échelles dans le zonage viticole. Bull l'OIV 74:301-318

Barbeau G (2007) Climat et vigne en moyenne vallée de la Loire, France. Congress on climate and viticulture, 10-14 April, Zaragosa, p 96-101

Barbeau G, Asselin C, Morlat R, Jacquet A, Pinard C (1998) Comportement du cépage Cabernet franc dans différents terroirs du Val de Loire. Incidence de la précocité sur la composition de la vendange en année climatique normale (Exemple 1998). J Int Sci Vigne Vin 32:69-81

Bindi M, Fibbi L, Gozinni B, Orlandini S, Miglietta F (1996) Modelling the impact of future climate scenarios on yield and yield variability of grapevine. Clim Res 7:213-224

Bonnefoy C, Quenol H, Planchon O, Barbeau G (2010) Températures et indices bioclimatiques dans le vignoble du Val de Loire dans un contexte de changement climatique. EchoGéo (online) 14. http://echogeo.revues.org/ 12146

Branas J (1974) Viticulture. Déhan, Montpellier

Briche E, Madelin M, Beltrando G, Kergomard C (2010)
Analyse comparative des températures extrêmes de 1950 à 2100 issues des modèles ARPEGE-Climat et LMD: intérêt pour l'activité viticole champenoise. Climatologie 7:9-19

Brisson N, Levrault F (2010) Changement climatique, agriculture et forêt en France: simulations d'impacts sur les principales espèces. Le Livre Vert du projet CLIMATOR (2007-2010). ADEME

Carbonneau A, Riou C, Guyon D, Riom J, Schneider C (1992) Agrométéorologie de la vigne en France. Office des Publications Officielles des Communautés Européennes, Luxembourg

Carey VA, Archer E, Barbeau G, Saayman D (2008) Viticultural terroirs in Stellenbosch, South Africa. II. The interaction of Cabernet-Sauvignon and Sauvignon blanc with environment. J Int Sci Vigne Vin 42:185-201

Champagnol F (1984) Eléments de physiologie de la vigne et viticulture générale. Dehan, Montpellier

Coombe BG (1987) Influence of temperature on composition and quality of grapes. Acta Hortic 206:23-35

Duchêne E, Schneider C (2005) Grapevine and climatic changes: a glance at the situation in Alsace. Agron Sustain Dev 25:93-99

Ganichot B (2002) Évolution de la date des vendanges dans les Côtes-du-Rhône méridionales. In: Actes des 6e Rencontres rhodaniennes. Institut rhodanien, Orange, p 38-41

> Garcia de Cortazar-Atauri I, Daux V, Garnier E, Yiou P and others (2010) Climate reconstructions from grape harvest dates: methodology and uncertainties. Holocene 20: 599-608

Huglin P (1978) Nouveau mode d'évaluation des possibilités héliothermiques d'un milieu viticole. In: Symposium International sur l'écologie de la vigne. 1. Ministère de l'Agriculture et de l'Industrie Alimentaire, Constança, p 89-98

IPCC (2007) Climate Change 2007: synthesis report. Contribution of Working Groups I, II and III to the Fourth Assessment Report of the Intergovernmental Panel on Climate Change (Core Writing Team: Pachauri RK, Reisinger A [eds]). IPCC, Geneva

Jackson RS (2008) Wine science: principles and applications, 3rd edn. Elsevier, New York, NY

Jones GV, Davis RE (2000) Climate influences on grapevine phenology, grape composition, and wine production and quality for Bordeaux, France. Am J Enol Vitic 51:249-261

> Jones GV, White MA, Cooper OR, Storchmann K (2005) Climate change and global wine quality. Clim Change 73: 319-343

Jones GV, Duff AA, Hall A, Myers JW (2010) Spatial analysis of climate in winegrape growing regions in the Western United States. Am J Enol Vitic 61:313-326

Laget F, Tondut JL, Deloire A, Kelly M (2008) Climate trends in a specific Mediterranean viticultural area between 1950-2006. J Int Sci Vigne Vin 42:113-123

Madelin M, Bois B, Chabin JP (2010) Modification des conditions de maturation du raisin en Bourgogne viticole liée au réchauffement climatique. L'exemple des vignobles de la Côte et des Hautes-Côtes de Beaune. EchoGéo (online) 14. http://echogeo.revues.org/12176

Moisselin JM, Dubuisson B (2006) Évolution des valeurs extrêmes de température et de précipitations au cours du XXe siècle en France. Meteorologie 54:33-42

Moisselin JM, Schneider M, Canellas C, Mestre O (2002) Les changements climatiques en France au XXe siècle. 
Étude de longues séries homogénéisées de données de température et de précipitations. Meteorologie 38:45-56 Morlat R (2010) Traité de viticulture de terroir. Lavoisier, Paris

Organisation Internationale de la Vigne et du Vin (OIV) (2010) Résumé des résolutions adoptées en 2010 par la 8ème assemblée générale de l'OIV. 20-27 June, Tbilisi

Pettitt AN (1979) A non parametric approach to the changepoint problem. Appl Stat 28(2):126-135

Quinn G, Keough M (2002) Experimental design and data analysis for biologists. Cambridge University Press, New York, NY

Ramos MC, Jones GV, Martínez-Casasnovas JA (2008) Structure and trends in climate parameters affecting winegrape production in northeast Spain. Clim Res 38:1-15

Ribéreau-Gayon P, Dubourdieu D, Donèche B, Lonvaud A (2006) Handbook of enology. The microbiology of wine and vinifications, Vol. 1, 2nd edn. John Wiley \& Sons, Chichester

Tesic D (2001) Environmental effects on cv Cabernet Sauvignon (Vitis vinifera L.) grown in Hawke's Bay, New Zealand. PhD thesis, Massey University, Palmerston North

Tomasi D, Jones GV, Giust M, Lovat L, Gaiotti F (2011) Grapevine phenology and climate change: relationships and trends in the Veneto region of Italy for 1964-2009. Am J Enol Vitic 62:329-339

Editorial responsibility: Gerrit Hoogenboom, Prosser, Washington, USA
Tonietto J (1999) Les microclimats viticoles mondiaux et l'influence du mesoclimat sur la typicité de la Syrah et du Muscat de Hambourg dans le sud de la France. PhD thesis, l'Institut National Recherche Agronomique, Paris

Tonietto J, Carbonneau A (2004) A multicriteria climatic classification system for grape-growing regions worldwide. Agric For Meteorol 124:81-97

Van Leeuwen C, Friant P, Xavier C, Tregoat O, Koundouras S, Dubourdieu D (2004) Influence of climate, soil, and cultivar on terroir. Am J Enol Vitic 55:207-217

Van Leeuwen C, Garnier C, Agut C, Baculat B and others (2008) Heat requirements for grapevine varieties is essential information to adapt plant material in a changing climate. VIIth International Terroir Congress, 19-23 May, Nyon, Proc (1): 222-227

Van Leeuwen C, Bois B, Cellie N, Tregoat O, Roby JP (2009) Les modifications de l'expression du terroir induit par les changements climatique nécessitent une adaptation du matériel végétal et des techniques viticoles. Rev Fr d'OEnol 235:10-14

Vaudour E (2003) Les terroirs viticoles. Définitions, caractérisation, protection. Dunod, Paris

Webb LB, Whetton PH, Barlow EWR (2008) Climate change and winegrape quality in Australia. Clim Res 36:99-111

Winkler AJ, Cook JA, Kliewer WM, Lider LA (1974) General viticulture, 2nd edn. University of California Press, CA

Submitted: May 23, 2011; Accepted: February 21, 2012

Proofs received from author(s): May 29, 2012 